\title{
INCREASING TRANSPARENCY AND PUBLICITY OF UKRAINIAN LOCAL BUDGETS
}

\section{LIUDMYLA DEMYDENKO}

PhD in Economics, Associate Professor, Taras Shevchenko National University of Kyiv, Ukraine ipr.demydenko@gmail.com

\section{YULIIA NAKONECHNA}

$\mathrm{PhD}$ in Economics, Associate Professor,

Taras Shevchenko National University of Kyiv, Ukraine

tematika@ukr.net

\section{NATALIIA MIEDVIEDKOVA}

$\mathrm{PhD}$ in Economics, Associate Professor,

Taras Shevchenko National University of Kyiv, Ukraine

nsmedvedkova@gmail.com

Abstract. The article is devoted to the study of directions for increasing transparency and publicity of local budgets. The study substantiates the need to improve the practice of using tools for increasing transparency and publicity, taking into account international experience, as well as identifies ways to increase the efficiency of using these tools in order to ensure the socioeconomic development of regions. The results of the study allow authors to develop directions for improving transparency and publicity of Ukrainian local budgets, which will help increase the efficiency of budgetary resources and the quality of public services.

\section{KEYWORDS: LOCAL BUDGETS, TRANSPARENCY, OPENNESS, PARTICIPATORY BUDGET, GENDER-ORIENTED BUDGET.}

For citation: Demydenko, L., Nakonechna, Y., \& Miedviedkova, N. (2021). Increasing Transparency and Publicity of Ukrainian Local Budgets. Globalization and Business. 12, 52-56. https://doi.org/10.35945/gb.2021.12.006

\section{FORMULATION OF THE PROBLEM}

In modern conditions, transparency and openness of the public administration system is a characteristic feature of countries with a democratic system. Thanks to transparency and openness, a dialogue is carried out between the local self-government body and citizens, which increases the degree of citizens' confidence in the authorities, the quality of the provision of public services and the level of efficiency in managing the budget process. In addition, an open and transparent policy is one of the conditions for cooperation with international financial organizations and increases the investment attractiveness of the country.

In 2019, the Open Budget Index of Ukraine increased by 9 positions and reached 63 out of 100 . At the same time, despite the positive dynamics, the country has something to strive for and study the practices of other countries: foremost, neighboring countries, where Romania and Slovenia occupy 64th and 68th place, respectively, as well as developed countries, where Germany and Great Britain occupy 69th and 70th place, respectively (Open Budget Survey, 2019).

Analysis of recent studies and publications and highlighting a part of the previously unsolved problem. Many domestic and foreign scientists are engaged in solving the problems of increasing the publicity and transparency of local budgets. Theoretical and practical aspects of publicity and transparency of local budgets occupy an important place in the research of such domestic scientists as L. Demydenko and Y. Nakonechna (2016), M. Lyvdar, N. Yaroshevych, I. Kondrat (2018), Yuriy S. and Kaspruk A. (2020), Nechyporenko A., Moroz L. and Panchenko I. (2021) and others.

Scholars Yuriy S. and Kaspruk A. investigated the theoretical foundations of a transparent budget process, namely, budget transparency and publicity as principles of organizing the budget system and participatory budgeting, which are effective means of public participation in the budget process. 
Researches L. Demydenko and Y. Nakonechna studied the procedure for publishing budget documents that affect the country's rating according to the budget transparency index.

Scientists Lyvdar M., Yaroshevych N. and Kondrat I. analyzed the best practices of local self-government in the field of transparency and public involvement in the budget process, identified their advantages and disadvantages, and also suggested ways to improve the involvement of citizens in the budget process. A group of researchers Nechyporenko A., Moroz L. and Panchenko I. analyzed the level of openness of the budget process in Ukraine in modern conditions of development and identified problematic aspects and shortcomings that impede publicity and transparency of the budget process in the country.

At the same time, the crisis phenomena in the economy, politics and public relations led to a decrease in the effectiveness of the use of budgetary resources by local governments, which, in turn, does not allow obtaining the desired indicators of socio-economic development. This situation actualizes the need to study the publicity and transparency of local budgets in order to increase the efficiency of resource allocation and improve the quality-of-service delivery, and also contributes to the fight against fraud and reduction of the level of corruption at the local level. Thus, the purpose of the article is to deepen the theoretical aspects of ensuring publicity and transparency of local budgets and substantiate practical recommendations for their improvement.

\section{Presentation of the main material}

The key components of the budget system are the principles of the budgetary structure, in particular the principle of publicity and transparency and the principle of subsidiarity, where the first principle provides for informing the public about the budgetary process at the local level, as well as control over the execution of budgets. And according to the second one - the principle of subsidiarity, which is a key principle of European democracy, budgetary services should be close to the direct consumer (Zubenko, 2017).

\section{Fig.1. Transparency in Ukraine compared to other countries}

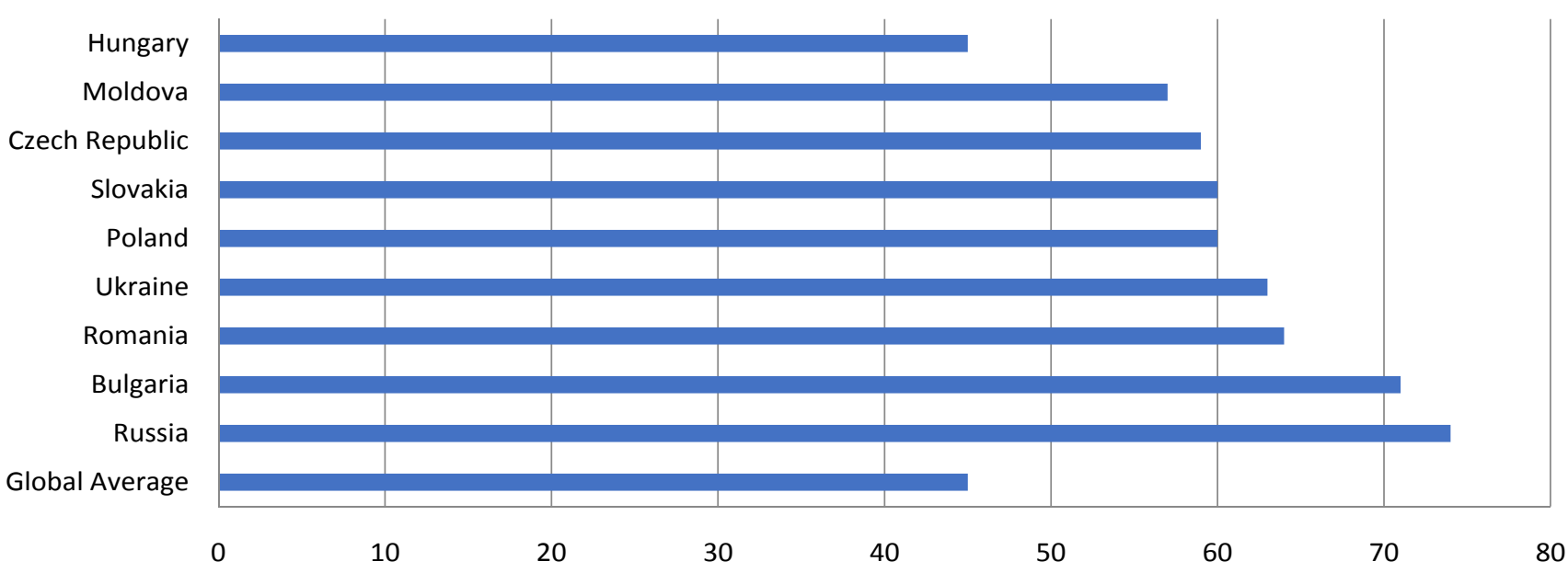

Source: Open Budget Survey 2019
The most successful examples of ensuring transparency of local budgets are the projects E-Data, ProZorro and DoZorro. E-Data is the official government information portal on the Internet that provides public information on the use of public funds and implements the idea of a "Transparent Budget", which allows, among other things, to reduce the level of fraud and corruption, increase the efficiency of the use of budget funds and Ukraine's international rating Open Budget Index.

ProZorro is an electronic government procurement system that uses commercial online platforms to register and connect users and organizers. After the launch of the Prozorro system, a lot of tools and services appeared in Ukraine that help to analyze and monitor purchases and their participants.

DoZorro Monitoring Portal is an online tool created to facilitate the monitoring and analysis of public procurement on the ProZorro Portal. To date, DoZorro-community includes 25 public organizations that have identified violations in 10 thousand purchases. It is important to note that the DOZORRO project development team has developed free training that will help to learn how to analyze purchases in the BI Prozorro public module. Participation in such training is useful both for beginners in procurement analytics and customers and participants (PROZORRO, 2021).

One rating that uses criteria to assess public access to central government budget information is the Open Budget Survey. It assesses public access to information on how the central government collects and spends public resources. It provides an assessment of the availability, timeliness and completeness of 8 key budget documents using 109 equivalent indicators and scores for each country on a scale from 0 to 100 .

In 2019, Ukraine's Open Budget Index reached 63 out of 100 , which is above the global average of 45 . An Openness Index of 61 and above indicates that the country is likely to publish enough material to support meaningful public debate on the budget. This is a significant result in comparison with other countries (Poland - 60, Slovakia - 60, Czech Republic 59, Moldova - 57, Hungary - 45) (fig.1) (Open Budget Survey, 2019). 
Significant steps towards increasing the openness of the budget in Ukraine have already been made. The most successful examples are E-Data, ProZorro and DoZorro projects. E-Data is the official government information portal on the Internet, which implements the idea of "Transparent Budget". The creation of the "Transparent Budget" system makes it possible to increase the efficiency of the use of budgetary funds and the international rating of Ukraine according to the Open Budget Index.

But transparency alone is not enough to improve public finance governance. Public participation in budgeting and local finance is essential for the positive outcomes associated with greater budget transparency. Participatory budgeting is one of the forms of democracy at the local level that provides a systematic approach to involving citizens in the process of making budget decisions for a particular territorial community. Thanks to participatory budgeting, citizens are empowered to make decisions about where to spend some of their public resources.

Today, one of the best ways to manage public funds is participatory budgeting, which is the most effective instrument among all instruments of democracy. Thus, participatory budgeting as a mechanism for the direct participation of citizens in decision-making on the use of public budgets is a globally recognized effective practice of participatory governance.

Since 2015, in Ukraine, participatory budgeting has been increasing not only in terms of the number of local selfgovernment bodies, but also in terms of the total amount allocated for the implementation of the ideas of residents (Shokalo, 2020).

The Open Budget Review also assesses the opportunities for the public to participate at different stages of the budget process. According to Public Participation Index, Ukraine has a public participation score of 33 (out of 100). This is a significant breakthrough in comparison with other countries, where Bulgaria ranks 26th, Poland - 24th, and the Czech Republic and Slovakia - 11th (fig.2) (Open Budget Survey, 2019).
Since 2015, in Ukraine, participatory budgeting has been increasing not only in terms of the number of local selfgovernment bodies, but also in terms of the total amount allocated for the implementation of the ideas of residents. During 2019-2020 most of the projects of citizens have already been implemented by such cities as Kramatorsk, Kiev, Dnipro, Ternopil, Chernivtsi and Khmelnitsky.

The victory of the draft public budget is significantly influenced by the support of city residents and voting for it. In turn, citizens should be well informed and involved in the voting process for it. During 2019-2020, there is a positive trend towards an increase in the share of citizens involved in the formation of participatory budgeting in most cities (Shokalo, 2020).

The international practice of participatory budgeting shows that active actions by non-governmental organizations and other public associations, constant public control, which in turn requires direct public participation at every stage of managing the participation budget, plays an important role. In doing so, it is important to consider the following:

Firstly, local self-government bodies should not "overlap" with the public budget the items of expenditures that must be financed by them. Thus, the draft budget should not relate to the direct responsibilities of local self-government bodies, but should take into account the ideas of citizens for the development of the city;

Secondly, local governments should implement projects on time, and not "freeze" them and postpone them "for later", because in the event of a "freeze" of the project, difficulties arise in resuming the organization of the voting process for the continuation of this project and its victory, as well as proving this project to its logical conclusion.

Gender-based budgeting (GBB) in Ukraine is funded by the Government of the Kingdom of Sweden through the Swedish International Development Agency (SIDA) to provide advisory support to the Ministry of Finance. The project "Gender Budgeting in Ukraine" began its work in Ukraine in

Fig.2. Public participation in Ukraine compared to other countries

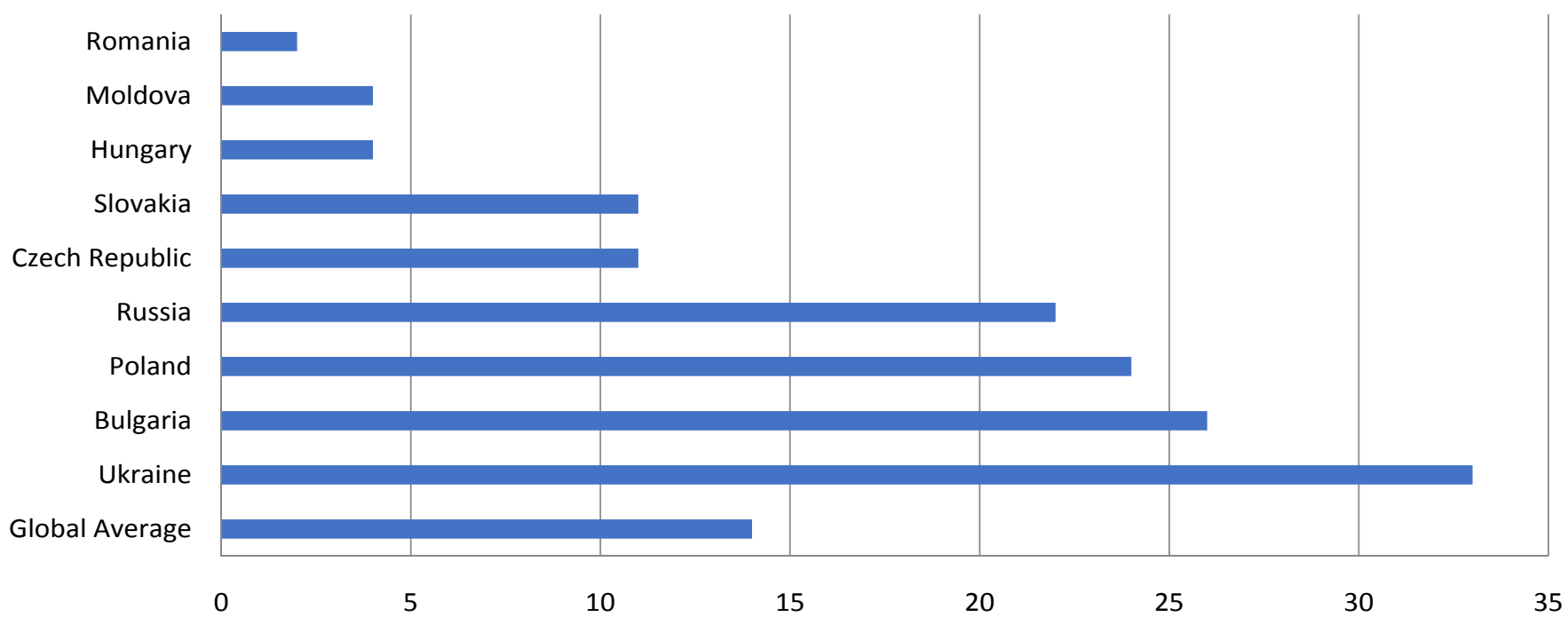

Source: Open Budget Survey 2019 
2013 and today is the largest in the world in the implementation of a gender-oriented approach in the budget process. A systematic approach to the use of GBB combines the financial and social aspects of the budget, and also helps to reduce gender gaps in Ukraine.

During 2015-2019, in all regions (except for Luhansk and Donetsk) and Kiev, working groups were created by order of the heads of the Regional State Administration, which carry out a number of measures to introduce GBB in their regions:

- conduct a gender analysis of programs financed from local budgets;

- develop recommendations and proposals on the inclusion of gender aspects in regulatory legal acts;

- carry out various events to disseminate knowledge about a gender-sensitive approach among other participants in the budget process.

During 2015-2019, 103 budget programs were analyzed in the field of education and science, health care, social protection and social security, culture and art, youth policy and physical culture and sports.

It is important to note that the Ukrainian experience of implementing and applying a gender approach in the budget process is of interest to the world: in 2019, a GIZ study tour was held for representatives of the countries of Armenia, Georgia and Azerbaijan (Ministry of Finance of Ukraine, 2020).

Noteworthy is the evaluation of the Gender Budgeting in Ukraine Project (2013 - 2020) and the evaluation report presented by Nordic Consulting Group (Stockholm, October $19,2021)$. The purpose of the assessment was to provide the Embassy and its partners with materials for future discussions on preparing further support for gender budgeting reform in Ukraine, as well as to facilitate programmatic activities in the context of Sweden's next strategy for cooperation with Eastern European countries in reform for 2021-2027.

Despite the introduction and dissemination of the practice of participatory and gender-based budgeting, there are practices that are overlooked by many studies. The fact is that these practices require considerable resources (time and money for the introduction of new technologies and training of workers), therefore they are not used or have a low level of implementation in countries. These practices are as follows:

1. Public audit of the budget (participatory audit), which allows citizens to fully exercise control over their expenditures. Such an audit brings together civil organizations, citizens and the Commission's auditors with one audit team. Its goal is to strengthen citizen participation in the public audit process in order to increase transparency and efficiency in the use of public resources. It is being implemented in such Asian countries (in particular, Cambodia and the Philippines), where its use made it possible to involve citizens in control over the use of funds, cooperation between regulatory bodies and citizens, as well as an increase in the financial discipline of authorities. At the same time, the need for special knowledge and a significant part of free time do not make it possible to use this tool in Ukraine (Golinsky \& Matvienko, 2017);

2. The visualization system "Open Budget" is a simple, convenient and understandable format for presenting budget information. On the only portal in the form of infographics, a citizen can get acquainted with the main budget indicators of his/her city or region, download the necessary documents, etc. The Open Budget system is a set of 9 interactive modules with the help of which a citizen can understand how the city government accumulates, distributes and uses city budget funds (Interactive visualization system "Open budget", 2020);

3. Tools for disclosing costs, including per-object disclosure of costs and various techniques for visualizing costs in real time. The purpose of these projects is to inform the public about budget spending, as well as the possibility of visual control by citizens.

The practice of object-by-object disclosure of costs requires additional time to update information. It is borrowed from the experience of Poland, and this practice is currently being disseminated and used in the Lviv and Rivne regions on the initiative of experts from the public environment and deputies. It provides for the weekly publication of information on the receipt of funds in the budget by source and by object;

And the technique of visualizing expenditures in real time (in particular, mapping) involves the automatic mapping of both planned and actual indicators of expenditures of the development budget of an administrative-territorial unit. Their purpose is to enable citizens to visually control their expenses: repairing houses and infrastructure, capital construction, landscaping and purchasing equipment in socially significant facilities. This practice is borrowed from the experience of Poland and is spreading in the cities of Ukraine (Golinsky \& Matvienko, 2017);

4. Online budget consulting tools, which are used to better understand the priorities of city residents in its development and contribute to the efficient allocation of funds and improve the provision of services and services. In addition, this tool ensures the formation of partnerships between the authorities and citizens, where citizens can influence the adoption of decisions that are important for the city, and local governments can receive support for their actions.

This tool is actively used in cities of the UK, which allows to attract potentially active and knowledgeable citizens who do not have time for meetings. In particular, the portals "Be Heard", "Birmingham says", "Our budget is based on what you said" and "Your city your say", through which city residents will be able to communicate their views and proposals for the development of the city, in particular, the distribution of the budget funds for construction, waste processing or social services (Consultation Hub; Manchester city council). The disadvantage of using this tool is the need to attract a permanent online consultant, as well as the cost of additional technical development of the online consulting platform. 


\section{CONCLUSIONS AND PROSPECTS FOR FURTHER RESEARCH IN THIS DIRECTION}

The process of reforming local finance in accordance with European requirements allows not only to improve the indicators of transparency, efficiency and control in the local finance management system, but also to raise the country's international ratings and create competitive advantages in attracting foreign investment.
The advantages of introducing the considered instruments are as follows: firstly, they allow everyone to control the budget process and budget execution; secondly, they contribute to a more efficient use of budgetary funds; thirdly, they reduce the likelihood of fraud and corruption at all stages of the budget process; finally, improving the international rating of Ukraine according to the Open Budget Index.

\section{REFERENCES:}

Budgeting process vs. citizen participation: the realities of public budgets in Ukrainian cities (2020). https://centreua.org/mistsevi-vibori-2020/byudzhetnij-proces-vs-uchast-gromadyan-realiyi-gromadskih-byudzhetiv-u-mistah-ukrayini/

Consultation Hub (2021, 8 November). https://www.birminghambeheard.org.uk/

Demydenko, L., \& Nakonechna, Y. (2016). Openness and transparency of State and Local Budgets in Ukraine. Bulletin of the Taras Shevchenko National University of Kyiv. Economy. 187, 20-27.

DOZORRO launched free BI PROZORRO trainings (2021, 24 October). https://infobox.prozorro.org/articles/dozorro-zapustiv-bezkoshtovni-trenuvannya-z-bi-prozorro

Gender-oriented budgeting at the local level (2021). https://mof.gov.ua/uk/283-genderno-oriientovane_biudzhetuvannia_ na_mistsevomu_rivni

Interactive visualization system "Open budget" (2015, 11 May). https://eidos.org.ua/interaktyvna-systema-vizualizatsiji-vidkrytyj-byudzhet/

Lyvdar, M.V., Yaroshevych, N.B., \& Kondrat, I.U. (2018). Transparency of the budget and public involvement in the budget process at the local level. Economy and Society, 17, 562-567. DOI: https://doi.org/10.32782/2524-0072/2018-17-83

Manchester city council. URL: http://www.manchester.gov.uk/info/500326/budget_201720/7407/how_we_ve_created_these_ proposals

Methodology for assessing the transparency of local budgets (2017). Ed. by Golinsky, O.V., Matvienko, A.O. K. Eastern Fund. Europe.

Nechyporenko, A.V., Moroz, L.O., \& Panchenko, I.V. (2021). Publicity and transparency of the budgetary process in Ukraine. Collection of scientific papers of the University of State Fiscal Service of Ukraine, 1, 186-198.

Open Budget Survey (2019). https://www.internationalbudget.org/open-budget-survey/country-results/2019/ukraine

Yuriy, S. \& Kaspruk, A. (2020). Transparency of budget process as ensuring the efficiency of budgetary reform. Bulletin of the Chernivtsi Trade and Economic Institute. Economic sciences, 1-2, 182-190. URL: http://nbuv.gov.ua/UJRN/Vchtei_2020_1-2_17

Zubenko, V.V. (2017) Suchasna biudzhetna systema: pravyla ta protsedury. K.: IBSED. (in Ukrainian). 